\title{
Correlation Value of the Mineralogical Composition of Tills in the North of European Russia
}

\author{
L. Andreicheva ${ }^{(\bowtie)}$ \\ Institute of Geology KomiSC UB RAS, Syktyvkar, Russia \\ andreicheva@geo.komisc.ru
}

\begin{abstract}
The material composition of the tills, including its mineral component, is formed during of the exaration-accumulative activity of the cover glacier and depends on the composition of the rocks of the glaciation centers, transit areas, local underlying rocks and on the relief of the preglacial bed. Thus the composition of the till is conditioned by the total influence of source glacier provinces and represents an average sample of the rocks on the way of the glacier.
\end{abstract}

Keywords: Mineral composition · Correlation · Till •

Petrographic composition

\section{Introduction}

The studies were conducted on a vast and geologically heterogeneous territory of the Timan-Pechora-Vychegda region, which determined the variability of lithological and mineralogical parameters of the tills in term of the regional plan. This restricts their use for correlations. But taking into account the factors of the glacial sedimentation genesis and the complex study of the tills, the stratigraphic confinement of moraine horizons is established very confidently. The features of the mineral-petrographic composition of the tills and the rocks of the source provinces (remote, transit and local) are discussed in detail in the papers by Andreicheva (1994, 2017).

\section{Results and Discussion}

Pomusovski (Okskii) till in the lower Pechora and Laya is characterized by a low content of a heavy fraction (0.26-0.4\%) and amphibole (10-12\%) - garnet (12-19\%) epidote $(35-41 \%)$ mineral association. The concentration of titanium minerals (rutile, titanite, leucoxene) is 7-9\%, the total amount of pyrite and siderite does not exceed 10$11 \%$. Eastward (in the valleys of the Kolvaand Pechora Rvers - in borehole 301Kushshor) the yield of the heavy fraction is significantly higher $-0.8-1.16 \%$, but the epidote content decreases (to 26-30\%), amphiboles (to 5-7\%) and the total concentration of pyrite and siderite increases sharply to $37 \%$. In borehole 301-Kushshor the 
number of garnets (up to 23\%) and the content of titanium minerals (up to 11\%) increase.

The decrease in the content of amphiboles in the Pomusovskitill eastward with the underlying Aptian and Albianrocks. They are characterized by the epidote-amphibole mineral association with a distinct W-E decreasing content of amphiboles. The enrichment of the heavy fraction with pyrite and siderite in the of Kolvavalley is associated with assimilation of these minerals from the Mesozoic sediments. The petrographic composition of the fragments and their south-eastward orientation testifies to the formation of the pomusovskytill in the region due to source from Fennoscandinavia and the Northern Timan.

The composition of the heavy fraction of Pechora(Dneprovian) till is also characterized by areal variability, reflecting the specifics of the mineral composition of the rocks of remote, transit and local source provinces. The minimum yield of the heavy fraction is $0.33 \%$, noted in Pechoratill in the middle Pechora River, the maximum $0.86 \%$, in the SeydaRver. The mineral association is represented by epidote, garnets, amphiboles, pyrite, siderite and ilmenite. In some areas, the role of titanium minerals increases, most often due to an increase in the amount of leucoxene, sometimes the content of metamorphogenic minerals is increased: kyanite, staurolite, sillimanite.

Epidote prevails in the Pechoratill, its quantity varies from 14 to $37 \%$. Maximum concentrations are recorded in sections of the middle Pechora, the lowest - in the ChernayaRver. The number of garnets is increased to $21 \%$ in the ShapkinaRver, reduced to $5 \%$ - on the valley of the SeydaRver. The content of amphiboles is low: its maximum concentration (16\%) is marked in the VychegdaRver, and the lowest - on the right bank of the UsaRver, where is only $0.6 \%$, which is associated with the complete absence of amphiboles in the underlying Mesozoic rocks. The amount of pyrite also varies significantly: its minimum content $(3 \%)$ is in the basin of the ShapkinaRver, the maximum in the SeydaRver- $27 \%$. Siderite in the LayaRver is $8 \%$, in the sections in the ChernayaRver reaches of $27 \%$, pyrite and siderite are constantly present. Their total concentrations are different, but the ratio is stable: almost everywhere siderite dominates pyrite. In the petrographic thin sections of the pechorskytill, glauconite is contained in significant quantities (up to 60 grains in a standard petrographic section), which, like pyrite, siderite, is characteristic of local Mesozoic rocks. The composition of the minerals of the heavy fraction testifies to the participation of underlying Triassic, Jurassic and Cretaceous rocks in the formation of the mineral spectrum of the till (Andreicheva and Nikitenko 1989). Single reference boulders are constantly present pink crinoid-bryozoan Novaya Zemlya limestones. Another characteristic feature of the Pechora glaciation is a steady south-western trend of ice movement, which is consistent with the petrographic composition of rock fragments in the till. The obtained data testify to the Paykhoy-Ural-Novaya Zemlya center of glaciation in the Pechora time throughout the region.

The peculiarity of the paleogeography of Vychegda (Moskovian) glaciation is the existence in the west and in the east of the region of the ice covers of various centers. Accordingly, the material composition of the till was formed by the material of 
different source provinces. In the western and central parts of the region, the heavy fraction of till, which ranges from $0.42 \%$ in the lower Pechora River to $0.95 \%$ in the Vychegda valley, is represented by an amphibole-garnet-epidote mineral association with increased total pyrite and siderite contents (up to $32 \%$ in the ChernayaRver valley in the north of the Bolshezemelskaya tundra). Sometimes the amounts of ilmenite and titanium minerals are increased. In the south of the region, the association of heavy minerals contains less epidote than in the Pechoratill, and there are more amphiboles and garnets, sometimes amphiboles reach $57 \%$ of the heavy fraction. Pyrite and siderite make up the first percentages of the weight of the heavy fraction, and ilmenite concentrations are increased (9-12\%). The amount of glauconite in Vychegdatill is 3-4 times lower than in Pechoratill: up to 15-20 grains per standard petrographic section. Heteroagedtills particularly sharply differ from one another by the composition of heavy minerals in the southern regions of the region. The orientation of the fragments in sector 270-3600 and the presence of indicator rocks of the North-West Terrigenous Mineralogical Province also indicate the migration of material from the west and from the north-west. Another feature of this till is the predominance of light colored limestones in the group of carbonate rocks.

In the northeast of the region, the mineral composition of the heavy fraction of the Vychegdatill is variable and consists of ilmenite (12\%), garnet (15\%), pyrite (15\%), siderite $(25 \%)$, epidote $(32 \%)$. The content of titanium minerals is slightly increased $10 \%$, and amphiboles - is decreased (4-12\%). The petrographic spectrum of fragments represents Uralian rocks. The fragments of rocks are oriented in sub latitudinal and SW directions, i.e. material for the formation of Vychegdatill came from the east-northeast.

The main mineral association of the Polar (Ostashkovian) till contains epidote (19$27 \%)$, garnets (14-20\%) and amphibole (11-16\%). The total content of siderite and pyrite is $13-35 \%$ with dominating of siderite. The crinoid-bryozoanNovaya Zemlya limestones are present. The orientation of detrital material from NNE to SSW confirms the onset of the cover glacier in polar time from Pay-Khoy-Novaya Zemlya.

\section{Conclusions}

Despite the variability of lithologic and mineralogical parameters of tills in terms of the regional plan, the data of the mineral composition of tills can be used with confidence for the dismemberment of Quaternary sections and wide spatial correlations of glacial deposits, taking into account the factors of glacial sedimentation genesis, as well as the petrographic composition of rock fragments and their orientation.

Acknowledgements. This research was supported by UB RAS project № 18-5-5-50 and project AAAA-A17-117121140081-7. 


\section{References}

Andreicheva LN (2017) Correlation of neopleistocene tills of the north of the Russian plain in petrographic composition. Lithol Miner (1):82-94. (in Russian)

Andreicheva LN (1994) The source provinces and their influence on the formation of the composition of the moraines of the Timan-Pechora-Vychegda region. Lithol Miner (1):127131. (in Russian)

Andreicheva LN, Nikitenko IP (1989) The mineral composition of the fine earths of the main moraines of the Timan-Pechora-Vychegda region. In: Mineralogy of the Timan-Northern Ural region, Syktyvkar, proceedings of the institute of geology, Komi SC UB RAS, no 72, pp 5262. (in Russian)

Open Access This chapter is licensed under the terms of the Creative Commons Attribution 4.0 International License (http://creativecommons.org/licenses/by/4.0/), which permits use, sharing, adaptation, distribution and reproduction in any medium or format, as long as you give appropriate credit to the original author(s) and the source, provide a link to the Creative Commons license and indicate if changes were made.

The images or other third party material in this chapter are included in the chapter's Creative Commons license, unless indicated otherwise in a credit line to the material. If material is not included in the chapter's Creative Commons license and your intended use is not permitted by statutory regulation or exceeds the permitted use, you will need to obtain permission directly from the copyright holder.

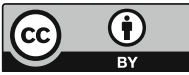

